\title{
The Effect of Consumer Behavior on Decision Visit to Seaworld Ancol Jakarta
}

\author{
Antonius Rizki Krisnadi ${ }^{1}$, Reinardy Onggo ${ }^{2}$ \\ ${ }^{1,2}$ UniversitasBundaMulia, \\ Email : ${ }^{1}$ akrisnadi@bundamulia.ac.id
}

\begin{abstract}
Consumer behavior is the behavior shown by consumers in searching, buying, using, evaluating, and using the products and services they expect to satisfy their needs. This study aims to determine the effect of consumer behavior on the decision to visit Seaworld Ancol.The type of research used is quantitative research. Samples are 100 respondents who are tourists. Sampling technique is Non-probability sampling with proposive sampling. The data analysis used is multiple linear regression analysis. The amount of influence of consumer behavior on the decision to visit Seaworld Ancol amounted to 33\%. Variables of personal and psychological factors positively affect the decision of visiting tourists.Based on these results, then put forward some suggestions are: 1) Seaworld Ancol party should conduct promotion on all sorts of circles not only for students, 2) To keep tourists to always come to Seaworld Ancol then need a more creative and innovative ideas in promoting both through print and electronic media and improve the quality and Service to tourists, 3) To maintain the tourists also need to provide adequate facilities and multiply attractions that can attract tourists to come.
\end{abstract}

Keywords - Consumer Behavior, cultural factors, social factors, personal factors, psychological factors, tourist visiting decisions

\section{INTRODUCTION}

One of the secondary needs of humans is recreation or traveling. Humans are required to always need an attractive means, providing tranquility, pleasure, and satisfaction. By doing casual activities humans can eliminate the feeling of fatigue and boredom from work. According to the Law of the Republic of Indonesia No.10 of 2009 on Tourism in question is a variety of activities supported by various facilities and services provided by the community, Entrepreneurs, and Local Government.

A place of tourism should be able to understand how tourists adapt from different forms of products, prices, services, and promotions. This can result in consumer decisions in selecting products, brands, or visiting times. Some of the tourist attractions offered by the provider companies, such as Theme Park, Mall, Swimming Pool, and Museum we can easily find, this is of course for tourists bored. Creating different and unique attraction to attract tourist to visited.

Jakarta has a wide range of recreational places ranging from historic places, shopping, entertainment, and religious venues. One of the major recreational places and attract tourists is Ancol Dream Park. Ancol is in the north of Jakarta more precisely on JalanLodanTimur No. 7, RW. 10, Ancol, Pademangan. Ancol has many interesting places that tourists can visit like the Fantasy World, Ocean Dream Ocean, Atlantis Water Adventure, Marine Ecopark, Art Market, Gondola and SeaworldAncol.

SeaworldAncol is one of the tourism places in Ancol and has a unique product that is offered to tourists a life under the sea that can be seen directly and even tourists can interact directly with some types of fish in SeaworldAncol. 
TABLE 1. TOTAL ARRIVAL TRAVELERS SEAWORLD ANCOL IN 2016

\begin{tabular}{lcc}
\hline No & Month & Total Visitors \\
\hline 1 & January & 76.273 \\
2 & February & 53.136 \\
3 & March & 68.123 \\
4 & April & 57.722 \\
5 & May & 93.414 \\
6 & June & 40.605 \\
7 & July & 136.095 \\
8 & August & 68.196 \\
9 & September & 60.773 \\
10 & October & 74.943 \\
11 & November & 74.284 \\
12 & December & 165.332 \\
\hline
\end{tabular}

Sources :Seaworld 2017

Based on the above table it is explained that in the calculation of the number of tourists who come to visit SeaworldAncol based on the number of entrance tickets purchased by tourists in the month. From the above data it can be concluded that the number of SeaworldAncol tourists has decreased and also the increase that only happened during the holiday that is like the month of July whose visit 136,095 different from the month of June which only 40.605, and at the time of December its visit 165.332 different from month November which is only 74,284. This is because in July and December is the school holiday period.

Therefore, knowledge about the behavior of tourists in determining the decision to visit and also the desires of tourists is needed by the company for the company to grow. In addition, the behavior of tourists is also influential in the decision to visit, so that the behavior of tourists affect the increase in the number of consumers and automatically will increase the amount of income.

Based on the background description of the above problems can be identified several problems that arise, among others:

1. The level of visits to SeaworldAncol Jakarta decreased and only increased during school holidays

2. The influence of consumer behavior on the increase and decrease of visits to SeaworldAncol Jakarta

3. Visiting decisions that affect the level of visits to Seaworld

In this research the problems encountered in the research process can be formulated as follows:

1. Can cultural factors influence visiting tourists visiting SeaworldAncol?

2. Can social factors influence travelers visiting SeaworldAncol?

3. Will personal factors influence the decision of tourists visiting SeaworldAncol?

4. Can psychological factors influence the decision of tourists visiting SeaworldAncol?

5. Will cultural, social, personal, psychological factors collectively influence the decision of tourists visiting SeaworldAncol? 
A study done certainly has several goals. The purpose of this research is:

1. To analyze whether cultural factors can influence the decision of visiting tourists to SeaworldAncol.

2. To analyze whether social factors can influence the decision of visiting tourists to SeaworldAncol.

3. To analyze whether personal factors can influence the decision of visiting tourists to SeaworldAncol.

4. To analyze whether the factors can influence psychology decision visiting tourists to SeaworldAncol.

5. To know what factors have the most influence in decision making visit to SeaworldAncol

The results of this research will be expected to provide usefulness for all parties, namely:

1. For the SeaworldAncol

The results of this study are expected to provide input for management to determine appropriate measures in an effort to increase the number of tourists with attention to factors that influence the decision of tourists in determining the decision to visit.

\section{For the Academic}

The results of this study are expected to be useful for readers to increase knowledge about the influence of products and prices on the tourist visiting decisions in SeaworldAncol Jakarta and also the results of this research can be useful for other researchers to conduct further research but with different content.

\section{For Researchers}

The results of this study can be used to add insight and experience in analyzing the problems that exist in the company, especially in the field of tourism.

\section{LITERATURE REVIEW}

\section{Tourism}

Tourism by McIntosh (in Muljadi ,2009,p.8) is "A composite of activities, services and industries that deliver a travel experience: transportation, accomodation, eating and drinking establishment, shops, entertainment, activity and other hospitality service available for individuals or group that are away from home. "

Tourism is a combination of activities, services and industries that provide travel experiences: transportation, accommodation, food and beverages, shops, entertainment, activities and other hospitality services available to individual or groups away from home. In essence Tourism is a combination of interactions between the government as the host of tourism, business, and tourists. 


\section{Tourism site}

According to Ridwan,(2012) p. 5 understanding of attractions is anything that has the uniqueness, beauty and value in the form of diversity of natural wealth, culture, and man-made products that become the target or purpose of tourist visits.

Based on the above definition can be concluded that the tourist attraction is everything that is in the tourist destination which is an attraction for tourists to want to visit the area. The goal is to have fun with time long enough to get satisfaction, good service, and beautiful memories at the sights.

\section{Tourist}

According to Law no. 10 Year 2009 Article 1 on tourism, tourists are people who do tourism activities. So according to that sense, everyone who travels is called tourists.

UN Conference on Interest Traveland Tourism in Irawan (2010, p. 12) tourists are visitors who come to a country they visit for 24 hours and with the aim to have fun, vacation, health, study, religious and sporting purposes, business, family, messengers and meetings.

UN. Convention Concerning CostumsFasilities for Touring in Irawan (2010: 12) Everyone who comes to a country for legitimate reasons, other than to immigrate and who stay for at least 24 hours and forever 6 months in the same year

Based on the above definition it can be concluded that tourists are visitors who live temporarily at least 24 hours in the region or country visited.

\section{Consumer behavior}

According to Kamuk (2007: 3) consumer behavior is defined as the behavior shown by consumers in searching, buying, using, evaluating, and using products and services they expect to satisfy their needs.

According to Callen - Marchione \& Ownbey (2008:365-383)in Journey of Fashion Marketing and Management explains consumer behavior as follows: "Consumer behavior according to the perceived level of" wrongness "of the unethical behavior. The subjects reported "switching price tags" subject to "getting too much change and not saying anything" subjects reported "getting too much change".

In understanding consumer behavior there are four factors that must be taken into account by the marketer in influencing consumer behavior according to Kotler and Amstrong (2008) are cultural, social, personal, and psychological factors.

\section{Cultural Factors}

Culture is the most basic determinant of desire and behavior to get the values, preferences, perceptions, and behaviors of other important institutions. Cultural factors have the greatest influence. Cultural factors consist of:

a. Culture

Culture is a collection of values, and habits that act to guide the behavior of the consumer and is the most fundamental cause of the behavior and desires that a community member learns from other important families and institutions.

According to Kotler and Amstrong (2008) who belong to this culture is a shift in culture and values in the family. 


\section{b. Sub culture}

Sub culture is part of culture. Each sub-culture consists of a smaller sub-culture or group of people with the same value system based on life experience. Sub-cultures include nationalities, religions, racial groups, and geographical regions.

c. Social class

Social class is a relatively permanent group of people in a society organized in order and its members share similar values, interests, and behaviors.

\section{Social Factors}

Social class is a relatively homogeneous and permanent division of a hierarchically organized society whose members have similar values, interests, and behaviors. Consumer behavior is also influenced by social factors, namely:

\section{a. Reference group}

Groups are two or more people that directly or indirectly influence the attitude of a person. Some are primary groups that have regular but informal interactions such as friends, family, and co-workers. Some are secondary groups, which have more formal and regular interactions. This includes organizations such as denominations, professional associations and trade unions.

\section{b. Family}

The family is the most important consumer buying organization in a society where family members can have a strong influence on one's purchase.

c. Roles and status

In each group, a person's position is determined in the form of his role and status. Role consists of activities that are expected to be done by someone according to the people around him. Each role carries a status that reflects the respect given by the community. Consumers often choose products that show their status in society.

\section{Personal Factors}

The definition of personal factors is defined as the psychological characteristics of a person different from others that lead to a relatively consistent and lasting response to the environment. Consumer behavior is also influenced by personal factors, namely:

a. Age and stage of life cycle

Age affects a person in buying products according to their needs orientation. Consumer tastes are always changing with age. There are other factors that influence the experience in the life cycle of a person.

b. Employment and economic situation

The better a person's work, the more his or her consumption pattern will increase. The economic situation can be reflected in personal income, savings, and interest rates. Selection of products will also be influenced by the state of one's economy.

c. Lifestyle 
Lifestyle is the lifestyle of a person expressed in activities, interests, and opinions that are more than just social class and personality. Lifestyle illustrates the pattern of one's interaction with the environment.

\section{d. Personality and self-concept}

Personality is a person's psychological characteristics that are different from others that lead to a relatively consistent and lasting response to his environment. Personality usually described in terms of properties such as self-confidence, domination, sociability, autonomy, self-preservation, adaptability, and aggression. Personality is useful for analyzing consumer behavior for brand or product selection. Selfconcept relates to personality such as active, creative, and so on.

\section{Psychological Factors}

Psychological factors are part of the environmental influx in which a person lives and lives in the present without neglecting the influence of the past or his anticipation in the future. Consumer behavior influenced by psychological factors is:

\section{a. Motivation}

Motivation is the drive from within a person to act to seek satisfaction or unmet needs. In order of importance, the level of needs is physiological, safety needs, social needs, self-actualization needs, and reward needs.

\section{b. Presentation}

Perception is the process by which an individual chooses, organizes and interprets information inputs in order to obtain a complete picture in the situation at hand, and each person has different perceptions.

\section{c. Learning process}

Learning is a picture of change in the individual behavior that comes from experience. The importance of this learning process for marketing is to shape the demand for a product by connecting it with a strong drive, using motivational clues, and providing a positive role. According to Kotler \& Armstrong (2008: 136) states: "Learning describes these changes an individual's behavior arising from experience. Learning theorists say that most human behavior is learned. Learning occurs through the interplay of drivers, stimuli, cues, responses, and reinforcement ".

\section{d. Trust and attitude}

Trust is a descriptive thought someone has about something. Trust is based on actual knowledge. While attitudes are the learned tendency toward what is judged or adjusted about an object that is liked or disliked. These beliefs and attitudes are usually acquired through learning and action. Marketers are convinced that customers are formulating specific products and services, because these beliefs make up brand image and products that affect buying behavior. If there is some mistake in the belief, then marketers would want to build a business to correct it. Attitude of feelings, expectations, consumer's evaluation of products and services offered consistent or in line with the expectations.

\section{Purchase Decision Process}

Consumer behavior will determine the decision-making process in their purchase. The decision-making process is a problem-solving approach consisting of five stages: 


\begin{tabular}{|c|c|c|c|c|}
\hline $\begin{array}{l}\text { Problem } \\
\text { Introduction }\end{array}$ & $\begin{array}{l}\text { Search } \\
\text { Information }\end{array}$ & $\begin{array}{l}\text { Alternative } \\
\text { Evaluation }\end{array}$ & $\begin{array}{l}\text { Buying } \\
\text { decision }\end{array}$ & $\begin{array}{l}\text { Post } \\
\text { Purchase }\end{array}$ \\
\hline & & & & Behavior \\
\hline
\end{tabular}

Fig 1. Purchase Decision Process

\section{Research paradigm}

Based on Kotler and Armstrong, Marketing Principles (2008: 160) there are 4 fundamental variables, where they are:

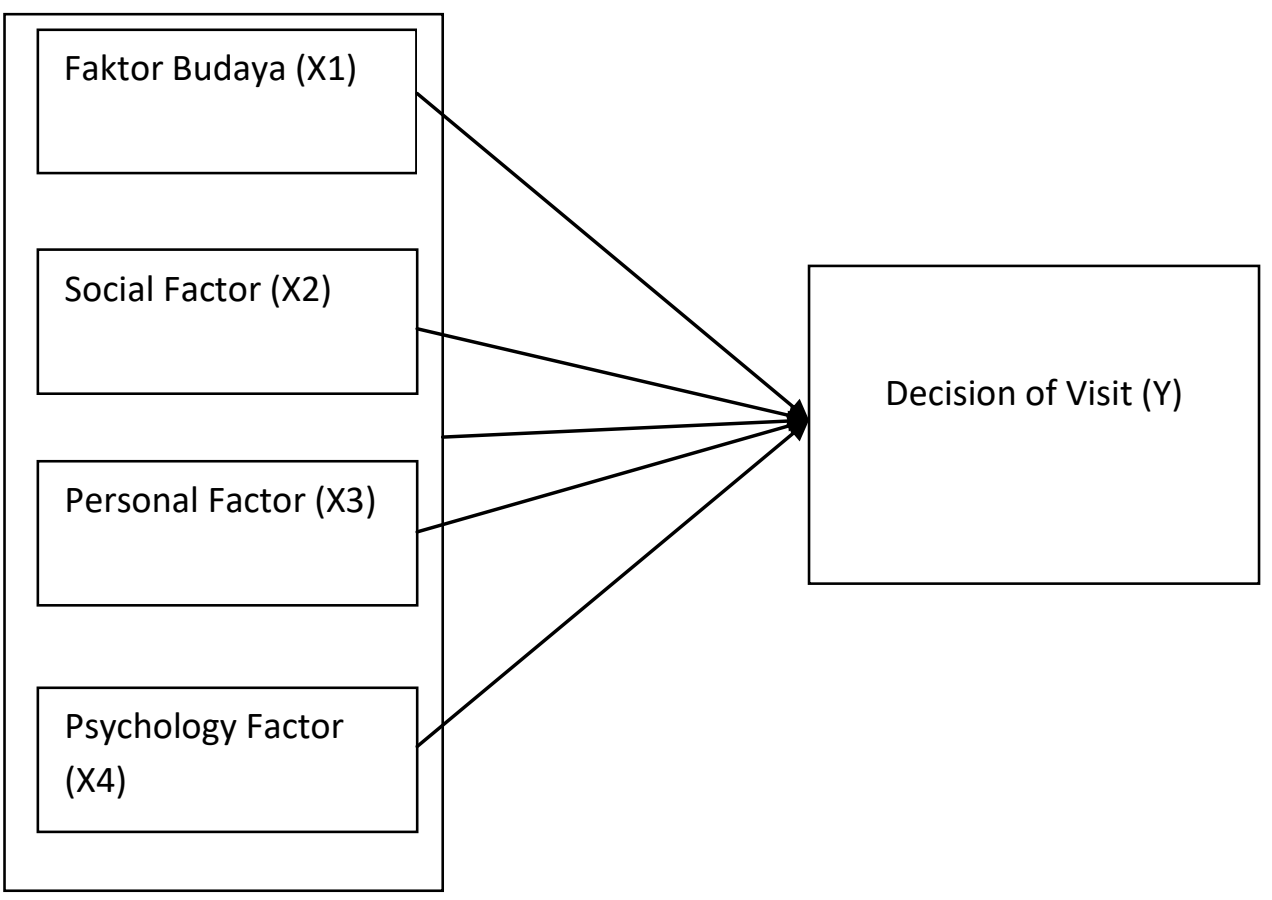

Fig 2. Research Paradigm 


\section{RESEARCH METHODOLOGY}

\section{Subject of Research}

The subject of the study is something, either person, object or institution (organization), which is the nature of the situation will be examined. The subject chosen in this study is a case study on SeaworldAncol visitors, North Jakarta who decided to visit SeaworldAncol. In its operations, SeaworldAncol has 3 major missions: Education, Conservation and Entertainment. Through this mission Sea World Ancol puts itself as a place of quality entertainment. In an effort to introduce the life of biota that live in nature, SeaWorld Ancol has about 7,300 freshwater biota consisting of 48 species of fish, 1 species of reptile to marine biota consisting of 11,500 head of biota consisting of 138 species of fish and invertebrates and 3 types reptile. The biota is featured in 28 displays divided into 9 freshwater aquariums and 19 aquariums as well as 4 open pools. SeaworldAncol operates daily from 09.00-1700 WIB for Weekday and 09.00-18.00.

In its operations, SeaworldAncol has 3 major missions: Education, Conservation and Entertainment. Through this mission Sea World Ancol puts itself as a place of quality entertainment. In an effort to introduce the life of biota that live in nature, SeaWorld Ancol has about 7,300 freshwater biota consisting of 48 species of fish, 1 species of reptile to marine biota consisting of 11,500 head of biota consisting of 138 species of fish and invertebrates and 3 types reptile. The biota are featured in 28 displays divided into 9 freshwater aquariums and 19 aquariums as well as 4 open pools. SeaworldAncol operates daily from 09.00-1700 WIB for Weekday and 09.00-18.00.

\section{Object of research}

The object of research is research variable, which is something which is the core of research problematical. In this study, the object of research is the factors of consumer behavior that influence the decision of tourists visiting SeaworldAncol.

\section{Types of research}

The type of research used is associative research. According to Sugiyono (2012: 54) associative research is research that aims to determine the influence or also the relationship between two variables or more.This research has the highest level compared with the descriptive and comparative because with this research can be built a theory that can work to explain, predict and control a symptom.

\section{Research variable}

According to Sugiyono (2012: 38) Variable research is an attribute or the nature or value of people, objects or activities that have a certain variation set by researchers 32 to study the specific variations applied by researchers to be studied and then drawn conclusions.

\section{Independent Variable}

According Sugiyono (2012: 39) Independent Variables in the Indonesian language is often referred to as independent variables. Independent variables are the variables that influence or the cause of change or the emergence of the dependent variable (bound). The free variable in this study is the dimension of consumer behavior consisting of culture, social, personal, psychological

\section{Dependent variable}


According Sugiyono (2012: 39) dependent variable in the Indonesian language is often called the dependent variable. The dependent variable is the variable that is affected or the result, because of the independent variables. The dependent variable in this study is the purchase decision.

\section{Population and Sample}

\section{Population}

Istijanto (2009: 113) Population is the total number that includes all members examined. The population in this study is tourists who visit SeaworldAncol Jakarta in 2016

\section{Sample}

Nanang (2010, p116) sample is part of the population that has certain characteristics or circumstances that will be studied so that it is expected to represent the population. The sampling technique used in this research is non-probability sampling with purposive sampling technique, with judgment sampling method. According to Sumarni\&Wahyuni (2006: 76-77) non-probability sampling is a sampling technique that does not provide equal opportunity for each element or member of the population to be elected as a sample member. The purposive sampling is a technique to take samples by adjusting themselves based on certain criteria or goals (deliberate).

SeaworldAncol Jakarta 2016 visitor population data is 968896 tourists, if the tolerable error factor is $10 \%$ then the number of samples required is Thus the number of samples rounded up to 100 tourists.

\section{Analysis Method}

In doing the data processing questionnaire that has been obtained, researcher uses Likert Scale. Likert scale according to Sugiyono (2013: 93) is the scale used to measure attitudes, opinions, and perceptions of a person or group of people about social phenomena.

\section{Stages Processing of Data}

TABLE 2. SCARING SCALE FOR POSITIVE AND NEGATIVE STATEMENT

\begin{tabular}{cccc}
\hline No & Description & Positive Score & Negative Score \\
\hline 1 & Strongly Agree & 5 & 1 \\
2 & Agree & 4 & 2 \\
3 & Normal & 3 & 3 \\
4 & Disagree & 2 & 4 \\
5 & Strongly Disagree & 1 & 5 \\
\hline
\end{tabular}

Source: Sugiono (2010: 94) 


\section{RESULTS AND DISCUSSION}

\section{Identity of Respondents}

\section{Gender}

This study used a sample of 100 respondents.

TABLE 3. IDENTITY OF RESPONDENT BY GENDER

\begin{tabular}{ccccc}
\hline No & Gender & Correspondent & Presentage (\%) \\
\hline 1 & Male & 66 & 66 \\
2 & Female & 34 & 34 \\
& & Total & $\mathbf{1 0 0}$ & $\mathbf{1 0 0}$
\end{tabular}

\section{Source: data processed by researchers}

Of the 100 respondents, most of the respondents were male (66\%) and 34 (34\%) respondents were female. Thus it can be said in this study that most of the respondents are predominantly male.

\section{Age}

Age greatly affects a person in every activity in his life. Because the age level will always be used as an indicator in determining whether or not a person productive, even influence the mindset and the standard of physical ability in a job.

TABLE 4. INDESTITY OF RESPONDENT BY AGE

\begin{tabular}{llcc}
\hline No & Age & Correspondent & Presentage (\%) \\
\hline 1 & $17-24$ Years old & 62 & 62 \\
2 & $25-34$ Years old & 22 & 22 \\
4 & $35-44$ Years old & 12 & 12 \\
5 & $>45$ Years old & 4 & 4 \\
& Total & $\mathbf{1 0 0}$ & $\mathbf{1 0 0}$ \\
\hline
\end{tabular}

Source: data processed by researchers

From 100 respondents, there were 62 people (62\%) at the age of 17-24 years old, then at the age of 25-34 years as many as 22 people (22\%), then at age 35-44 years there were 12 people (12\%) and above 45 years old as many as 4 people (4\%). Based on the results of the identity of respondents above age it can 
be seen that most respondents who researched in this study has the age level of 17-24 years. This is in accordance with the mission of Ancol as a place for Education, Conservation, and Entertainment.

\section{Activity}

To find out the number of Ancol Sea world tourists based on the work can be seen from the following table:

TABLE 5. IDENTITY RESPONDENT BY ACTIVITY

\begin{tabular}{|c|c|c|c|}
\hline No & Activity & Correspondent & Presentage $(\%)$ \\
\hline 1 & Student & 53 & 53 \\
\hline 2 & $\begin{array}{l}\text { Private Sector } \\
\text { Employee }\end{array}$ & 19 & 19 \\
\hline 3 & $\begin{array}{l}\text { Government } \\
\text { Employee }\end{array}$ & 8 & 8 \\
\hline 4 & Entrepreneur & 14 & 14 \\
\hline 5 & Housewife & 6 & 6 \\
\hline 6 & Others & 0 & 0 \\
\hline & Total & 100 & 100 \\
\hline
\end{tabular}

Source: data processed by researchers

Of the 100 respondents who were sampled in this study, most of the work was 53 students (53\%) and private sector (19\%), self-employed 14 persons (14\%), civil servants $8 \%$, housewives $6 \%$ and others did not exist. This proves that the more dominant students. This is also evidenced from the age-dominated age of 17-24 years who is a student.

\section{Data Analysis and Interpretation}

\section{Quality Test Data}

\section{Validity Test}

Validity analysis used is product moment correlation test and processed using SPSS program. 
TABLE 6. RECAPITULATION VALIDITY TEST RESULTS

\begin{tabular}{|c|c|c|c|c|}
\hline Variabel & Question & r qount & $\mathrm{r}$ table & Description \\
\hline \multirow{3}{*}{ Culture Factor } & 1 & 0,622 & \multirow{20}{*}{0,197} & Valid \\
\hline & 2 & 0,614 & & Valid \\
\hline & 3 & 0,602 & & Valid \\
\hline \multirow{3}{*}{ Social Factor } & 1 & 0,687 & & Valid \\
\hline & 2 & 0,417 & & Valid \\
\hline & 3 & 0,712 & & Valid \\
\hline \multirow{5}{*}{ Personal Factor } & 1 & 0,458 & & Valid \\
\hline & 2 & 0,534 & & Valid \\
\hline & 3 & 0,536 & & Valid \\
\hline & 4 & 0,568 & & Valid \\
\hline & 5 & 0,421 & & Valid \\
\hline \multirow{3}{*}{$\begin{array}{l}\text { Psychology } \\
\text { Factor }\end{array}$} & 1 & 0,641 & & Valid \\
\hline & 2 & 0,432 & & Valid \\
\hline & 3 & 0,550 & & Valid \\
\hline \multirow{6}{*}{$\begin{array}{l}\text { Decision of } \\
\text { Visit }\end{array}$} & 4 & 0,658 & & Valid \\
\hline & 1 & 0,494 & & Valid \\
\hline & 2 & 0,576 & & Valid \\
\hline & 3 & 0,624 & & Valid \\
\hline & 4 & 0,651 & & Valid \\
\hline & 5 & 0,574 & & Valid \\
\hline
\end{tabular}

Source: SPSS 2017

\section{Reliability Test}

Reliability analysis is an index showing the level of strength of a reliable and reliable measuring device. For reliability testing done by cronbach alpha technique. A research instrument is considered reliable if the value of alpha $>0.60$. 
TABLE 7. RELIABILITY TEST VARIABLE RESEARCH

\section{Research Variable Cronbach Alpha Acceptance Limits Description}

\begin{tabular}{lccc}
\hline Culture Factor & 0,703 & 0,60 & Reliabel \\
Social Factor & 0,705 & 0,60 & Reliabel \\
Personal Factor & 0,666 & 0,60 & Reliabel \\
Psychology Factor & 0,699 & 0,60 & Reliabel \\
Decision of Visit & 0,724 & 0,60 & Reliabel
\end{tabular}

Source: SPSS 2017

\section{Simultaneous Test (F-Test)}

To examine whether the hypothesis that cultural, social, personal, and psychological factors have a significant influence on the decision to visit the SeaworldAncol is acceptable or not, a variance analysis is needed to test the hypothesis simultaneously (F-Test).

TABLE 8. SIMULTANEOUS TEST (F-TEST)

\begin{tabular}{|l|r|r|r|r|l|}
\hline Model & $\begin{array}{r}\text { Sum of } \\
\text { Squares }\end{array}$ & Df & $\begin{array}{r}\text { Mean } \\
\text { Square }\end{array}$ & F & Sig. \\
& & & & & a \\
1Regression & 195.058 & 4 & 48.765 & 11.676 & .000 \\
Residual & 396.782 & 95 & 4.177 & & \\
Total & 591.840 & 99 & & & \\
\hline
\end{tabular}

Source: SPSS 2017

Value of F-Count obtained for 11.676 and F-table value of 2.32 (appendix 7). Thus, F-count $(11,676)>$ Ftable (2.32). Since F-count > F-table, then Ho is rejected and Hi is accepted. This means that the variables of cultural, social, personal and psychological factors simultaneously have a significant effect on visiting decisions. Thus the hypothesis which states that the behavior of tourists have an influence on the decision to visit the SeaworldAncol simultaneously acceptable.

\section{Partial Test (t-Test)}

The t-test is the test used to test the average equality of the independent variables used in the study. T test is analyzed by comparing t-count with $t$-table. If $t$-count $>t$-table with a significant level (alpha) $5 \%$ of 1.98 then the independent variables have a positive influence on the dependent variable. Based on the calculation results using SPPS obtained regression coefficient of independent variables as follows: 
TABLE 9. PARTIAL TEST (T-TEST)

\begin{tabular}{|cc|c|c|c|c|c|}
\hline \multirow{2}{*}{} & \multirow{2}{*}{ Model } & \multicolumn{2}{|c|}{$\begin{array}{c}\text { Unstandardized } \\
\text { Coefficients }\end{array}$} & $\begin{array}{c}\text { Standardized } \\
\text { Coefficients }\end{array}$ & & \\
\cline { 3 - 5 } & & $\mathrm{B}$ & Std. Error & Beta & $\mathrm{t}$ & Sig. \\
\hline 1 & (Constant) & 6.430 & 2.517 & & 2.555 & .012 \\
& X1 & .043 & .125 & .029 & .345 & .731 \\
& X2 & .114 & .102 & .098 & 1.121 & .265 \\
& X3 & .317 & .094 & .319 & 3.392 & .001 \\
& X4 & .378 & .110 & .319 & 3.430 & .001 \\
\hline
\end{tabular}

Source : SPSS 2017

Based on table that the cultural factor variable (X1) has a t-count of $0.345<\mathrm{t}$-tabel 1.98. From this test it can be concluded that the social factor variable partially has no effect on the decision to visit SeaworldAncol. This shows that the hypothesis is not accepted and the cultural factor variables have no positive effect on the visiting decision.

The social factor variable (X2) has a t-count of 1.121>t-table 1.98. From this test it can be concluded that the social factor variable partially has no effect on the decision to visit SeaworldAncol. This shows that the hypothesis is not accepted and the social factor variable has no positive effect on the visiting decision.

The personal factor variable (X3) has a t-count of 3.392> t-table 1.98. From this test it can be concluded that the personal factor variables partially affect the decision to visit SeaworldAncol. This means that the higher the personal factor, the higher the decision to visit AncolSeaworld. This suggests that the hypothesis is accepted and that the personal factor variable has a positive influence on the visiting decision.

Psychological factor variable (X4) has t-count of 3,430>t-table 1,98. From this test, it can be concluded that psychological factor variable partially influence to decision of visit to SeaworldAncol. This means that the higher the personal factor, the higher the decision to visit AncolSeaworld. This shows that the hypothesis is accepted and the psychological factor variable has a positive influence on the visiting decision.

Psychological factor variable (X4) has t-count of 3,430>t-table 1,98. From this test, it can be concluded that psychological factor variable partially influence to decision of visit to SeaworldAncol. This means that the higher the personal factor, the higher the decision to visit AncolSeaworld. This shows that the hypothesis is accepted and the psychological factor variable has a positive influence on the visiting decision.

From the results of testing the regression coefficient of each independent variable above can be concluded that there are two independent variables (personal and psychological factors) have an influence on the decision to visit the SeaworldAncol. This is indicated by the computed value of personal and psychological factors greater than $t$ table. Of these free variables, psychological factors have a more dominant influence on the decision to visit SeaworldAncol. This is because the psychological factor is greater than the personal factor. 


\section{CONCLUSIONS}

Based on the results of research that has been done, it can be concluded as follows:

1. Based on the test of validity and reliability, the results of all variables studied are social, personal, cultural, and psychological factors valid and reliable.

2. Based on the test simultaneously (F-test) obtained the value Fcount $(11,676)>$ F-table $(2.32)$. This test proves that the variables of social, personal, cultural and psychological factors together significantly influence the decision of tourists visiting SeaworldAncol.

3. Based on the partial test (t-test), two independent variables (personal and psychological factors) have tcount $>$ t-table, meaning that independent variables have an influence on customer satisfaction.

4. Of the two independent variables psychological factors have a more dominant influence on the decision of visiting. This is indicated by the value of psychological factors $t$-count is greater than $t$-table of personal factors.

\section{SUGGESTION}

1. Seaworld Ancol party should conduct promotion on all sorts of circles not only for students, but to other circles. This is because tourists who come to SeaworldAncol not only students but many others?

2. To keep tourists to always come to SeaworldAncol then need a more creative and innovative ideas in promoting both through print and electronic media and improve the quality and service to tourists.

3. To maintain the tourists also need to provide adequate facilities and multiply attractions that can attract tourists to come.

\section{REFERENCES}

A.J, Muljadi. (2009). Kepariwisataan dan Perjalanan. Jakarta: PT. Raja Grafindo Persada.

Irawan, Koko. (2010). Potensi objek wisata sebagai daya Tarik wisata. Yogyakarta:Kertas Karya.

Istijanto. (2009). Aplikasi Praktis Riset Pemasaran. Jakarta: Gramedia Pustaka Utama.

Karen S. Callen-Marchione, Shiretta F. Ownbey. (2008). "Association Of Unethical Consumer Behaviour and Social Attitudes". Journal of Fashion Marketing and Management: An International Journal, Vol. 12 Isuue: 3, pp.365-383.

Kotler, Philip dan Amstrong Garry. (2008). Prinsip-Prinsip Pemasaran jilid 1. Jakarta:Erlangga.

Martono, Nanang. (2010). Metode peneltiian kuantitatif. Jakarta: PT. Raya Grafindo Persada.

Ridwan, Mohamad.(2012).Perencanaan dan penegmbanagan pariwisata. PT Sofmedia : Medan

Schiffman, Leon G, dan Lesli Lazer Kanuk. (2007). Perilaku Konsumen edisi ketujuh.Jakarta: PT. Indeks. 
Sugiyono. (2012). Metode Penelitian Kuantitatif Kualitatif dan R\&B. Bandung:Alfabeta.

Sugiyono. (2013). Statistika Untuk Penelitian. Bandung:Alfabeta.

Sumarni dan Wahyuni.(2006). Metodologi Penelitian danBisnis. Yogyakarta: Penerbit Andi. Indonesian republic Act 10 of 2009 